\title{
PENGEMBANGAN MODEL PEMBELAJARAN PENDIDIKAN MULTIKULTURAL BERBASIS PROYEK DI SMA
}

\author{
Lia Prastyawati, Farida Hanum \\ SMA Negeri 7 Purworejo, Universitas Negeri Yogyakarta \\ meeza_ln@yahoo.com, faridahanum@uny.ac.id
}

\begin{abstract}
Abstrak
Penelitian ini bertujuan untuk mengembangkan model pembelajaran pendidikan multikultural di SMA, yang meliputi: 1) mengembangkan model pembelajaran pendidikan multikultural yang sesuai diterapkan dalam mata pelajaran sosiologi di SMA dan; 2) mengetahui kelayakan produk hasil pengembangan model pembelajaran pendidikan multikultural pada mata pelajaran sosiologi di SMA. Penelitian ini merupakan penelitian pengembangan yang mengacu pada model pengembangan 4D Thiagarajan yang meliputi empat tahap yaitu define, design, develop dan disseminate. Hasil penelitian terdiri dari: 1) model pembelajaran pendidikan multikultural yang dikembangkan menggunakan metode 4D Thiagarajan yang telah dimodifikasi menjadi 3D. 2) Produk pengembangan model pembelajaran pendidikan multikultural berbasis proyek telah mendapatkan penilaian dari validasi ahli, validasi materi, guru sosiologi, teman sejawat, hasil penilaian menyatakan produk layak digunakan dalam pembelajaran sosiologi di SMA. Produk pengembangan model pembelajaran pendidikan multikultural berbasis proyek telah diuji coba pada kelompok kecil dan uji coba lapangan. Hasil uji coba menunjukkan produk layak digunakan, dibuktikan dengan peningkatan nilai yang signifikan pada kelas yang menggunakan model pembelajaran pendidikan multikultural berbasis proyek dibandingkan dengan kelas yang menggunakan model pembelajaran pendidikan multikultural dengan metode ceramah dengan media power point.
\end{abstract}

Kata kunci: pendidikan multikultural, model pembelajaran berbasis proyek

\section{DEVELOPING A MODEL OF PROJECT BASED MULTICULTURAL EDUCATIONAL LEARNING AT SENIOR HIGH SCHOOL}

\begin{abstract}
This research aims at developing a model of project based multicultural educational learning at senior high school, which includes: 1) staging of developing the model of project based multicultural educational learning which is acceptable in sociology subject at senior high school level; and 2) finding out the product worthiness of the model of project based multicultural educational learning in sociology subject at senior high school. This research is a development study which is based on 4D Thiagarajan's development model which has four stages: define, design, develop and disseminate. The research findings are: 1) a model of multicultural educational learning developed through Thiagarajan's 4D method which has modified into 3D. The 2) The product of development model of project based multicultural educational learning got assessment from an expert validator, material validator, sociology teacher, and peers. The results show that the product is worth to be applied in the learning subject of sociology at senior high school. The product of development model of project based multicultural educational learning was tested in a small group and field tryout. The results show that the product is worth to be applied which is proved through more significant improvement scores at the class which used the model of project based multicultural educational learning than lecturing method using power point.
\end{abstract}

Keywords: multicultural education, project based learning model 


\section{Pendahuluan}

Indonesia adalah negara multikultural terbesar di dunia. Hal ini dibuktikan Indonesia adalah negara yang terdiri dari bebagai macam keragaman baik secara historis, sosial, kultural maupun geografis. Berdasarkan uraian mengenai negara Indonesia diperlukan penanaman pendidikan multikultural bagi warga negara Indonesia. Penanaman sejak dini dan pendampingan dalam proses pendidikan multikultural hingga menginjak dewasa sangat dibutuhkan, sehingga anak diharapkan mampu memahami bahwa lingkungan tempat tinggalnya terdapat berbagai macam keragaman. Apabila generasi penerus bangsa kurang memahami dan menerima secara bijaksana keragaman di Indonesia, maka akan timbul berbagai masalah seperti konflik dan benturanbenturan kepentingan dalam kehidupan masyarakat Indonesia. Hal ini telah ditunjukkan gejala-gejalanya selama ini seperti konflik Sampit, konflik Poso, bom-bom di area peribadatan menjelang hari raya suatu agama, serta masih banyak lagi konflik yang timbul akibat keanekaragaman yang terdapat di Indonesia (Yaqin, 2005, p. 25).

Salah satu strategi yang dapat ditempuh untuk meminimalisir konflik dan benturan yang ada di Indonesia adalah dengan pendidikan multikultural. Pendidikan multikultural menawarkan suatu alternatif melalui penerapan strategi dan konsep pendidikan yang memanfaatkan berbagai keanekaragaman yang ada dalam lingkungan masyarakat, khususnya lingkungan kehidupan siswa, seperti keragaman etnis, agama, budaya, gender, bahasa, status sosial, ras dan kemampuan umum. Sasaran utama dalam penanaman pendidikan multikultural adalah untuk mencapai tujuan utamanya, yaitu mencetak generasi yang mampu mengakomodasi berbagai keragaman yang ada sehingga dapat meminimalisir terjadinya berbagai konflik sebagai bekal ketika siswa terjun dalam kehidupan masyarakat luas.

Pendidikan multikultural di Indonesia diajarkan secara terintegrasi beberapa mata pelajaran tertentu. Di jenjang Sekolah Menengah Atas (SMA) salah satu mata pelajaran yang diintegrasi dengan pendidikan multikultural adalah Sosiologi. Namun dalam proses pembelajaran sosiologi pendidikan multikultural yang telah ada belum memberikan manfaat secara nyata bagi pembentukan kepribadian siswa yang sesuai dengan nilainilai multikulturalisme. dibuktikan dengan kurangnya toleransi siswa terhadap perbedaanperbedaan yang ada di sekolah seperti budaya mengutamakan laki-laki, mengejek teman yang berkemampuan rendah, mentertawakan teman yang mempunyai kebiasaan yang berbeda, korupsi waktu, menyontek saat pelajaran, penyelenggaraan kegiatan baik sekolah non-formal yang masih mengganggu jam-jam peribaatan agama tertentu, budaya senioritas dan lain sebagainya. Hal ini sangat bertentangan dengan apa yang diajarkan dalam pendidikan multikultural.

Penelitian ini bertujuan untuk mengembangkan model pembelajaran pendidikan multikultural di SMA, yang meliputi: 1) mengembangkan model pembelajaran pendidikan multikultural yang sesuai diterapkan dalam mata pelajaran sosiologi di SMA dan; 2) mengetahui kelayakan produk hasil pengembangan model pembelajaran pendidikan multikultural pada mata pelajaran sosiologi di SMA.

Pendidikan multikultural adalah salah satu strategi yang dihadirkan dalam pendidikan untuk memahami kondisi realita masyarakat Indonesia yang kaya akan keragaman diberbagai dimensi kehidupan. Jauh sebelum didengungkan di Indonesia pendidikan multikultural telah lama ada dalam masyarakat Eropa, Amerika Serikat dan di negara-negara maju lainnya. Gagasan ini bukanlah merupakan sesuatu yang baru, namun pengembangan dari studi interkultural dan multikulturalisme. Dalam perkembangannya, studi ini menjadi sebuah studi khusus tentang pendidikan multikultural. Menurut Montalto (Yaqin, 2005, p. 23) pendidikan multikultural pada awalanya bertujuan agar populasi mayoritas dapat bersikap toleran terhadap pendatang baru, serta mempunyai tujuan politis yaitu sebagai alat kontrol antara penguasa terhadap warganya agar negara aman dan stabil.

Pendidikan multikultural yang berkembang di Amerika Serikat adalah pendidikan yang bersifat antarbudaya etnis yang besar, yaitu budaya antarbangsa. Terdapat empat jenis dan empat fase perkembangan pendidikan multikultural di Amerika (Bank, 2004, p. 4) yaitu: (1) pendidikan yang bersifat segregasi; (2) pendidikan konsep Salad Bowl; (3) konsep melting pot; (4) pendidikan multi- 
kultural melahirkan suatu pedagogik baru serta pandangan baru mengenai praksis pendidikan yang memberikan kesempatan serta penghargaan yang sama terhadap semua anak tanpa membedakan asal usul serta agama.

Musa Asya'rie (2004) mengemukakan bahwa pendidikan multikultural bermakna sebagai proses pendidikan cara hidup menghormati, tulus, toleransi terhadap keragaman budaya yang hidup di tengah-tengah masyarakat plural, sehingga peserta didik kelak memiliki kekenyalan dan kelenturan mental bangsa dalam menyikapi konflik sosial di masyarakat. Perbedaan-perbedaan pada diri anak didik yang harus diakui dalam pendidikan multikultural, antara lain mencakup penduduk minoritas etnis dan ras, kelompok pemeluk agama, perbedaan agama, perbedaan jenis kelamin, kondisi ekonomi, daerah/asalusul, ketidakmampuan fisik dan mental, kelompok umur, dan lain-lain. Melalui pendidikan multikultural ini anak didik diberi kesempatan dan pilihan untuk mendukung dan memperhatikan satu atau beberapa budaya, misalnya sistem nilai, gaya hidup, atau bahasa.

Sementara itu di negara Indonesia pendidikan multikultural dilatarbelakangi oleh pengalaman kelam seperti kekerasan, pemberontakan, pembumihangusan, pembunuhan generasi, yang menimbulkan perpecahan dan ancaman disintegrasi bangsa yang terjadi sejak zaman kerajaan Singosari, Sriwijaya, Majapahit, Goa, dan Mataram serta berlangsung sampai era terkini. Pembunuhan pada era pengikut Partai Komunis Indonesia 1965, konflik etnis Madura-Dayak 1931-2000, kekerasan terhadap etnis China di jakarta 1998, konflik Islam-Kristen 1999-2003, hingga yang terkini adalah konflik-konflik antar umat beragama yang sering menyebabkan kerusakan dan hilangnya nyawa seperti perusakan tempat peribadatan, pengeboman, bahkan sampai kasus penodaan terhadap agama lain (Yaqin, 2005, p. 25). Urgensi pendidikan multikultural sangat diperlukan sebagai salah satu suplemen untuk memutuskan tali rantai sejarah kelam kekerasan antar berbagai unsur di Indonesia. Menurut Banks (2004, p. 28) pendidikan multikultural adalah konsep, ide atau falsafah sebagai suatu rangkaian kepercayaan (set of believe) dan penjelasan yang mengakui dan menilai pentingnya keragaman budaya dan etnis di dalam membentuk gaya hidup, peng- alaman sosial, identitas pribadi, kesempatankesempatan pendidikan dari individu, kelompok maupun negara.

Bentuk pengembangan pendidikan multikultural dalam setiap negara berbedabeda sesuai dengan latar belakang masalah yang dihadapi. Bank (2004) menjelaskan empat pendekatan yang mengintegrasikan materi pendidikan multikultural ke dalam kurikulum maupun pembelajaran yang apabila dicermati relevan untuk diterapkan dalam pendidikan Indonesia. Pendekatan-pendekatan tersebut antara lain adalah: (1) pendekatan kontribusi; (2) pendekatan aditif; (3) pendekatan transformasi, dan; (4) Pendekatan aksi sosial.

Model pembelajaran adalah pola yang digunakan sebagai pedoman dalam merencanakan pembelajaran di kelompok maupun tutorial (Suprijono, 2011, p. 46). Trianto (2010, p. 51) menyatakan model pembelajaran adalah suatu perencanaan atau suatu pola yang digunakan sebagai pedoman dalam merencanakan pembelajaran di kelas atau pembelajaran tutorial. Fungsi model pembelajaran adalah sebagai pedoman bagi perencana pengajar dan para guru dalam proses pembelajaran. Berbeda dengan pendapat di atas Saiful Sagala (2010, p. 176) menjelaskan bahwa model pembelajaran adalah suatu kerangka konseptual yang berisi prosedur-prosedur sistematik dan mengorganisasikan pengalaman belajar siswa untuk mencapai tujuan belajar tertentu yang berfungsi sebagai pedoman guru dalam proses belajar mengajar.

Model pembelajaran berbasis proyek atau disingkat PBP menurut diskripsi Patton (2012, p. 13) adalah "Project based learning refers to students designing, planning, and carrying out an extended project that produces a publicly-exhibited output such as a product, publication, or presentation". Artinya pembelajaran berbasis proyek ditujukan kepada siswa untuk mendesain, merencanakan dan membuat produk akhir untuk dipublikasikan atau dipresentasikan kepada khalayak umum.

Lamert dari The Buck Institute of Education (2006) mendefinisikan PBP adalah sebuah metode pengajaran yang sistematis yang melibatkan para siswa dalam pembelajaran pengetahuan dan keterampilan melalui proses penyelidikan diperpanjang terstruktur sekitar kompleks, pertanyaan otentik dan produk yang dirancang dengan hati-hati dan 
tugas. Lain halnya dengan pendapat Purworini (2006, p. 17) yang mengidentifikasikan PBP sebagai langkah-langkah pembelajaran untuk mencapai tujuan pembelajaran tertentu yang dilakukan melalu proyek dalam jangka waktu tertentu dengan melalui langkah-langkah: persiapan/ perencanaan, pelaksanaan, pembuatan laporan serta mengkomunikasikan hasil kegiatan serta evaluasi.

Model pembelajaran berbasis proyek memiliki keuntungan antara lain: (1) meningkatkan motivasi belajar siswa, (2) meningkatkan kemampuan pemecahan masalah, (3) meningkatkan kolaborasi. Pentingnya kerja kelompok dalam proyek menyebabkan siswa mampu mengembangkan dan mempraktikkan keterampilan komunikasi dan kinerja ilmiah siswa, (4) meningkatkan keterampilan mengelola sumber yaitu bertanggung jawab untuk menyelesaikan tugas yang kompleks (Thomas, 2000).

Langkah-langkah dalam penerapan Model Pembelajaran Berbasis Proyek yang diterapkan dalam penelitian ini mengacu pada langkah-langkah yang diadaptasi dari Mergendoller, et al., (2006), yang meliputi: (1) perencanaan proyek (project planning), (2) pelaksanaan proyek (project launch), (3) penyelidikan terbimbing dan pembuatan produk (guided inquiry and product creation), dan (4) kesimpulan proyek (Project Conclution). Sedangkan untuk model pembelajaran langsung, langkah-langkah penerapannya mengacu pada langkah-langkah yang diadaptasi dari Joyce \& Weil (1972), yang meliputi: 1) menyampaikan tujuan dan mempersiapkan siswa, 2) presentasi dan demonstrasi, 3) membimbing pelatihan, 4) mengecek pemahaman dan memberikan umpan balik, dan 5) memberikan kesempatan untuk pelatihan lanjutan dan penerapan.

Auguste Comte dalam Soekanto (2006, p. 4) mengemukakan bahwa sosiologi merupakan ilmu pengetahuan kemasyarakatan umum yang merupakan hasil terakhir dari perkembangan ilmu pengetahuan. Sosiologi lahir pada saat-saat terakhir perkembangan ilmu pengetahuan, oleh karena itu sosiologi didasarkan pada kemajuan-kemajuan yang telah dicapai ilmu yang lainnya.

Sosiologi merupakan ilmu sosial yang ojeknya adalah masyarakat. Sosiologi (Soekanto 2006, p. 15) adalah ilmu pengetahuan yang berdiri sendiri karena telah memenuhi segenap unsur-unsur ilmu pengetahuan yaitu bersifat empiris, teoritis, komulatif dan nonetis. Dalam kedudukan sebagai displin ilmu sosial yang sudah relatif lama berkembang di lingkungan akademika, secara teoritis sosiologi mempunyai posisi strategis dalam membahas dan mempelajari masalah-masalah sosial-politik dan budaya yang berkembang di dalam masyarakat dan selalu siap dengan pemikiran kritis dan alternatif menjawab tantangan yang ada pada saat ini.

Menurut Surachman yang dikutip oleh (Widjajanti, 2008), LKS merupakan jenis hand out yang dimaksudkan untuk membantu siswa belajar secara terarah. Keberadaan LKS memberi pengaruh yang cukup besar dalam proses belajar mengajar, sehingga penyusunan LKS harus memenuhi berbagai persyaratan misalnya syarat didaktik, syarat konstruksi, dan syarat teknik.

\section{Metode Penelitian}

Penelitian ini merupakan penelitian pengembangan yang mengadaptasi dari model pengembangan Thiagarajan atau disebut dengan metode Four-D (4-D) (Thiagarajan 1974, p. 5). Tahapan pengembangan terdiri dari empat tahap yaitu pendefinisian, perencanaan, pengembangan dan penyebarluasan.

\section{Prosedur Pengembangan}

Pelaksanaan 4 tahapan dalam penelitian ini adalah sebagai berikut: Pada tahap pendefinisian terdiri dari beberapa langkah yaitu setelah melakukan observasi awal maka dapat didefinsikan beberapa syarat pengembangan dalam penelitian ini antara lain adalah: (1) berdasarkan observasi awal diperoleh informasi bahwa pendidikan multikultural dalam dunia pendidikan merupakan sesuatu yang baru dan belum banyak dikembangkan model pembelajarannya di sekolah-sekolah. Selain itu pendidikan multikultural yang ada di sekolah selama ini kurang aplikatif sehingga implementasi dalam dunia yang sebenarnya masih kurang; (2) Karakteristik peserta didik di SMA N 7 Purworejo memungkinkan untuk dijadikan sebagai model pengembangan, selain input peserta didik yang bagus dari segi teknologi juga mendukung; (3) Analisis tugas merupakan pemahaman tugas dalam pembelajaran berbasis proyek untuk mengidentifikasikan struktur materi ajar pendidikan multikural dalam bentuk garis besar isi materi. 
Hasil dari analisis tugas ditentukan lembar kerja siswa sebagai panduan untuk menyampaikan tugas-tugas materi pendidikan multikultural yang dikemas dalam pembelajaran berbasis proyek; (4) Analisis konsep berisikan analisis terhadap materi-materi pendidikan multikultural yang akan dikembangkanan dalam model pembelajaran berbasis proyek. Analisis ini bertujuan agar siswa lebih memahami konsep-konsep pendidikan multikultural sehingga dapat mengimplementasikan dalam tes hasil belajar ataupun kehidupan sehari-hari; (5) Berdasarkan analisis tugas dan analisis konsep digunakan sebagai acuan penyusunan perumusan indikator pencapaian hasil belajar dan tujuan pembelajaran, sebagai penjabaran dari kompetensi inti dan kompetensi dasar. Perumusan tujuan pembelajaran merupakan dasar untuk mendesain perangkat pembelajaran dan penyusunan tes.

Tahap perancangan terdiri dari: (1) Dalam penelitian ini media yang dipilih adalah lembar kerja siswa (LKS). Penyusunan draft awal LKS sekurang-kurangnya memuat: (a) judul LKS yang menggambarkan materi; (b) tujuan yang akan dicapai siswa setelah mempelajari materi pendidikan multikultural; (c) prosedur atau kegiatan untuk siswa dalam mempelajari materi dengan menggunakan LKS; (d) tugas dan soal-soal latihan yang berhubungan dengan eksperimen yang akan dikerjakan oleh siswa dan digunakan untuk mengukur hasil belajar siswa. (2) Pemilihan format pembelajaran, dilakukan dengan mengkaji perangkat pembelajaran yang sudah ada kemudian dianalisis dan disesuaikan dengan isi pendidikan multikultural, sehingga tujuan yang dimaksud dapat tersampaikan. (3) Desain awal perangkat pembelajaran. Berisikan draft 1 rencana pelaksanaan pembelajaran pendidikan multikultural berbasis proyek yang disertai lembar kerja siswa.

Tahap Pengembangan pada tahap ini bertujuan untuk menghasilkan draf perangkat pembelajaran, yang telah direvisis oleh para penelaaah. Tahap ini terdiri dari dua langkah yaitu: (1) Validasi penelaah. Perangkat pembelajaran sebelum digunakan harus melalui tahap validasi yang bertujuan untuk memperbaiki desain awal perangkat (draft 1). Validasi ini dilakukan oleh ahli materi dan ahli media, dosen pembimbing, guru sosiologi, dan teman sejawat yang memahami tentang perangkat pembelajaran tersebut. Setelah draft 1 di- validasi dan direvisi maka akan dihasilkan draft 2 yang siap diujicobakan ke siswa. (2) Uji coba dengan siswa dilakukan dua kali yaitu: (a) uji coba terbatas dilaksanakan untuk mengecek keterlaksanaan perangkat, kecocokan waktu, kerja alat dan sebagainya. Hasil dari uji coba terbatas akan digunakan sebagai masukan, koreksi dan perbaikan terhadap draft 2 dan menghasilkan draft 3. (b) Uji coba lapangan merupakan implementasi perangkat pembelajaran yang berorientasi pada model yang akan diterapkan. Uji coba ini merupakan uji coba lebih lanjut yang diterapkan pada siswa dalam kelas yang sesungguhnya..

Tahap penyebarluasan adalah penggunaan model belajar yang telah dikembangkan pada skala yang lebih luas seperti kelas lain dan guru lain. Tujuan tahap ini adalah untuk menguji efektivitas model pembelajaran dalam kegiatan pembelajaran.

\section{Desain Uji Coba}

Uji coba produk dilakukan dengan dua tahap, yaitu dengan uji coba 1 (uji coba kelompok kecil) dan uji coba 2 (uji coba lapangan). Uji lapangan dengan menggunakan desain control group pretest-postest design. Menurut Sugiyono (2010, p.113) dalam penelitian ini terdapat dua kelompok yang dipilih secara random, kemudian diberi pretes, perlakuan yang berbeda (treatment) dan postes. Hal ini bertujuan untuk mengetahui adanya perbedaan antara kelas kontrol dan kelas eksperimen sebelum dan setelah diberikan perlakuan yang berbeda.

\section{Subjek Uji Coba}

Subjek uji coba dalam penelitian pengembangan ini adalah siswa SMA Negeri 7 Purworejo kelas XI jurusan IPS semester 2 tahun pelajaran 2013/2014. Subjek uji coba 1 (uji kelompok kecil) adalah 10 siswa kelas XI.IPS.1 yang dipilih secara acak. Subjek uji coba 2 (uji coba lapangan) adalah 60 siswa yang terdiri dari 30 siswa untuk kelas kontrol dan 30 siswa untuk kelas eksperimen, yaitu masing-masing adalah siswa kelas XI.IPS 2 sebagai kelas kontrol dan XI.IPS 3 sebagai kelas eksperimen.

Data

Data dalam penelitian ini terdiri dari dua jenis yaitu: (1) Data primer yaitu data 
mengenai kelayakan model pembelajaran berbasis proyek yang dituangkan RPP dan LKS untuk materi pendidikan multikultural berbasis proyek dari hasil pengembangan. Data yang dikumpulkan berupa hasil validasi dari ahli, dosen pembimbing, guru sosiologi, teman sejawat dan data hasil uji coba. (2) Data sekunder Data sekunder adalah data yang diperoleh dari kegiatan pembelajaran. Data tersebut meliputi ketercapaian dari hasil proyek yang dipresentasikan subjek uji coba serta nilai latihan subjek uji coba telah mencapai KKM atau belum antara kelas kontrol dan kelas eksperimen.

Instrumen

Instrumen penelitian ini adalah kuesioner, pedoman observasi dan tes hasil belajar. Kuesioner dengan kriteria penilaian angket menggunakan skala Likert. Skala likert yang digunakan dalam penelitian ini adalah 4 skala likert. Tes hasil belajar menggunakan tes objektif yang terlebih dahulu di uji validitas dan reliabilitasnya.

\section{Teknik Analisis Data}

Pengolahan data dalam penelitian ini menggunakan analisis deskriptif kuantitatif yang meliputi: analisis kelayakan, respon siswa, penilaian jawaban pada soal latihan dalam LKS dan keterlaksanaan pembelajaran. Analisis kelayakan dan respon siswa dilakukan dengan langkah-langkah berikut: (1) Tabulasi data untuk semua komponen, sub komponen dari butir penilaian yang tersedia dalam instrumen penilaian. (2) Menghitung skor total rata-rata dari setiap komponen. (3) Mengubah skor rata-rata menjadi nilai dengan kategori. Untuk mengetahui kualitas RPP dan LKS hasil pengembangan dari aspek materi maupun aspek media, serta untuk mengetahui respon siswa terhadap LKS, maka dari data yang mula-mula skor, diubah menjadi data kuantitatif (interval) dengan skala lima.

Uji perbedaan hasil belajar kelas kontrol dan kelas eksperimen. Uji ini dilakukan untuk mengetahui ada tidaknya perbedaan hasil belajar siswa yang menggunakan pembelajaran berbasis proyek. Sebelumya analisis data dilakukan uji-t terlebih dahulu dilakukan uji prasyarat analisis (uji normalitas dan uji homogenitas.
Analisis keterlaksanaan RPP. Penilaian terhadap keterlaksanaan fase-fase pengajaran dalam model pembelajaran berbasis proyek dilakukan oleh pengamat yang sudah terlatih sehingga dapat menilai dengan lembar observasi secara objektif. Kriteria yang dimaksud adalah fase-fase dalam pembelajaran berbasis proyek dapat terlaksana atau tidak terlaksana.

\section{Hasil dan Pembahasan}

Hasil Pengembangan

Hasil penelitian pengembangan ini adalah model pembelajaran pendidikan multikultural yang dikembangkan menggunakan metode 4D Thiagarajan yang telah dimodifikasi menjadi 3D. Tahapan penelitian pengembangan terdiri dari tahap define, design, dan develop. Tahap pendefinisisan dilakukan analisis kurikulum dengan menganalisis kompetensi inti dan kompetensi dasar yang sesuai dengan pendidikan multikultural. Tahap perencanaan berisi tahapan untuk mengembangkan pendidikan multikultural yang menggunakan motode pembelajaran berbasis proyek yang pengembangannya dituangkan dalam Rencana Pelaksanaan Pembelajaran (RPP) dan menggunakan media Lembar Kerja Siswa (LKS) dalam materi Pendidikan Multikultural. Pada tahap pengembangan Hasil dari tahap pengembangan meliputi: (a) validasi dari ahli materi yang dilakukan oleh Dr. Taat Wulandari yang merupakan ahli materi multikulturalisme; (b) validasi ahli media yang dilakukan oleh Dr. Aman, M.Pd yang merupakan ahli media pembelajaran; (c) validasi teman sejawat melibatkan alumnus Pendidikan Sosiologi Universitas Negeri Yogyakarta Feny Kusumawati, S.Pd.; (d) validasi guru sosiologi dilakukan oleh guru sosiologi SMA Negeri 7 Purworejo Dra. Suprapti Handayani; (e) uji coba kelas kecil dilakukan di kelas XI.IPS.1 SMA Negeri 7 Purworejo dengan jumlah peserta 10 siswa; (f) uji coba lapangan dilakukan di kelas XI.IPS. 3 SMA Negeri 7 Purworejo, yang kemudian dibandingkan hasil pembelajarannya dengan siswa yang yang tidak menggunakan pembelajaran pendidikan multikultural berbasis proyek, disini menggunakan pembelajaran klasikal dengan metode ceramah dengan media power point. 
Hasil Uji Coba Produk

Tabel 1. Data Hasil Evaluasi Produk untuk Ahli Materi

\begin{tabular}{clcc}
\hline No. & Indikator Penilaian & Skor & Ket. \\
\hline 1. & Kelayakan Isi & 10,0 & Baik \\
2. & Aspek Kebahasaan & 8,0 & Baik \\
\hline
\end{tabular}

Penilaian validasi ahli materi memperoleh penilaian "baik" dengan beberapa saran diantaranya adalah menambah lagi daftar buku referensi.

Tabel 2. Data Hasil Evalusi Produk Ahli Media

\begin{tabular}{clcc}
\hline No. & $\begin{array}{l}\text { Indikator } \\
\text { Penilaian }\end{array}$ & Skor & Ket. \\
\hline 1. & Penyajian & 23,0 & Sangat Baik \\
2 & Kegrafikan & 13,0 & Sangat Baik \\
\hline
\end{tabular}

Penilaian dari ahli media "sangat baik" dengan beberapa revisi antara lain memperbaiki ukuran kertas dan ukuran huruf.

Tabel 3. Data Evaluasi Produk RPP dan LKSTeman Sejawat

\begin{tabular}{lcc}
\hline No. Indikator Penilaian & Skor & Ket. \\
\hline 1. Perumusan Tujuan & 16,0 & Sangat baik \\
$\begin{array}{l}\text { 2. Pemilihan Materi } \\
\text { 3. Skenario/ Kegiatan }\end{array}$ & 19,0 & Sangat baik \\
$\begin{array}{l}\text { Pembelajaran } \\
\text { 4. Sumber belajar dan }\end{array}$ & 6,0 & Sangat baik \\
$\quad$ Media Pembelajaran & & Baik \\
5. Penilaian & 4,0 & Sangat baik \\
6. Kelayakan Isi & 11,0 & Baik \\
7. Aspek Kebahasaan & 12,0 & Sangat baik \\
8. Penyajian & 20,0 & Sangat baik \\
9. Kegrafikan & 14,0 & Sangat baik \\
\hline
\end{tabular}

Penilaian dari teman sejawat rata-rata mendapatkan nilai "sangat baik" dengan saran memperbaiki tata letak materi.

Penilaian dari guru sosiologi mendapatkan nilai "sangat baik" dengan saran memperbanyak gambar dan ditata lebih menarik lagi.

Hasil penilaian validator menunjukkan bahwa tahap pengembangan dapat dilanjutkan pada tahap berikutnya. Yaitu pada tahapan uji coba kelompok kecil dan uji coba lapangan.
Tabel 4. Data Hasil Evaluasi Produk RPP dan LKS Guru Sosiologi

\begin{tabular}{lccc}
\hline No. Indikator Penilaian & Skor & Ket. \\
\hline 1. Perumusan Tujuan & 15,0 & Sangat baik \\
2. Pemilihan Materi & 20,0 & Sangat baik \\
3. Skenario/ Kegiatan & 9,0 & Sangat baik \\
& Pembelajaran & & \\
4. Sumber belajar dan & 7,0 & Sangat baik \\
& Media Pembelajaran & & \\
5. Penilaian & 3,0 & Baik \\
6. Kelayakan Isi & 14,0 & Sangat baik \\
7. Aspek Kebahasaan & 12,0 & Sangat baik \\
8. Penyajian & 22,0 & Sangat baik \\
9. Kegrafikan & 14,0 & Sangat baik \\
\hline
\end{tabular}

Pada tahap uji coba lapangan keterlaksanaan RPP adalah 92,3\%, hal ini dikarenakan ada satu tahap yang tidak terlaksana yaitu presentasi hasil temuan yang disebabkan keterbatasan waktu yang diberikan sekolah kepada peneliti.

Pada tahap uji coba lapangan diperoleh dua data, yaitu keterlaksanaan RPP dan nilai hasil belajar. Keterlaksanaan RPP adalah $100 \%$ karena semua tahap dalam RPP dapat dilaksanakan. Data hasil belajar antara kelas yang menggunakan pembelajaran pendidikan multikultural berbasis proyek dengan kelas yang menggunakan pembelajaran pendidikan multikultural dengan metode ceramah dengan media power poin dapat dilihat dalam rangkuman tabel dibawah ini:

Tabel 5. Hasil Uji t Respon Kelas Eksperimen dan Kelas Kontrol

\begin{tabular}{ccccc}
\hline \multicolumn{1}{c}{ Kelas } & $\begin{array}{c}\text { Rata-rata } \\
\text { Peningkatan } \\
\text { Pretes ke postes }\end{array}$ & t hit & t tab & $\mathrm{P}$ \\
\hline Eksperimen & 37.466 & 7.112 & 2,001 & 0.000 \\
Kontrol & 30.033 & & & \\
\hline
\end{tabular}

Dari data diatas dapat dilihat bahwa peningkatan hasil belajar antara kelas yang menggunakan pembelajaran pendidikan multikultural berbasis proyek dengan kelas yang menggunakan pembelajaran pendidikan multikultural dengan metode ceramah dengan media power point mempunyai perbedaan yang signifikan, Peningkatan hasil belajar pada kelas yang menggunakan model pembelajaran pendidikan multikultural berbasis 
proyek lebih besar dibandingkan dengan hasil belajar pada kelas yang menggunakan pembelajaran pendidikan multikultural dengan metode ceramah dengan media power point

Selain dilihat dari nilai hasil tes belajar, dilihat juga melalui respon siswa terhadap kedua pembelajaran yang diberikan, yang dapat dilihat dalam histogram pada Gambar 1.

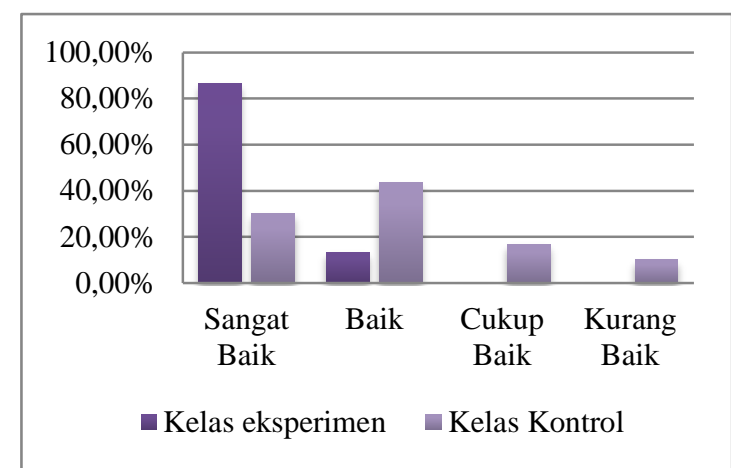

Gambar 1. Respon siswa kelas kontrol dan kelas eksperimen terhadap pembelajaran yang diberikan

Dari histogram diatas dapat diperoleh informasi bahwa respon siswa terhadap pembelajaran pendidikan multikultural berbasis proyek lebih tinggi dibandingkan dengan respon siswa terhadap pembelajaran pendidikan multikultural dengan metode ceramah dengan media power point.

\section{Simpulan dan Saran}

Simpulan

Berdasarkan hasil analisis data dan pembahasan yang telah dilakukan dapat disimpulkan: Model pembelajaran pendidikan multikultural dalam penelitian ini dikembangkan menggunakan metode 4D Thiagarajan yang telah dimodifikasi menjadi 3D. Tahapan penelitian pengembangan terdiri dari tahap define, design, dan develop. Define dalam tahap ini adalah untuk mendefinisikan kebutuhan-kebutuhan di dalam proses pembelajaran, dalam tahap ini terdapat lima langkah yaitu, pra-penelitian, analisis siswa, analisis konsep, analisis tugas dan perumusan pembelajaran. Design dalam tahap ini adalah pemilihan format dan desain awal pembelajaran yang akan dibuat. Develop dalam tahap ini adalah validasi RPP dan media yang akan digunakan dalam pembelajaran dan revisi.
Produk yang dihasilkan adalah model pembelajaran pendidikan multikultural berbasis proyek yang diwujudkan dalam rencana pelaksanaan pembelajaran dan media pembelajaran lembar kerja siswa.

Produk hasil pengembangan model pembelajaran pendidikan multikultural berbasis proyek setelah mendapatkan penilaian dari validasi ahli, validasi materi, guru sosiologi dan teman sejawat dinyatakan layak untuk diterapkan dalam pembelajaran sosiologi di SMA. Penjabaran penilaian tersebut dapat dilihat sebagai berikut: (a) Ahli materi menilai dari aspek kelayakan isi dan aspek kebahasaa, kedua aspek mendapat nilai "baik"; (b) Ahli media menilai dari aspek penyajian dan kegrafikan, kedua aspek mendapat nilai "sangat baik". Penilaian guru sosiologi dan teman sejawat diberikan pada aspek perumusan tujuan, pemilihan materi, skenario pembelajaran, sumber/ media pembelajaran, penilaian, aspek kelayakan isi, kebahasaan, penyajian dan kegrafikan. Nilai yang diberikan oleh guru sosiologi dan tema sejawat asalah "sangat baik". Selain dari penilaian ahli, produk pengembangan model pembelajaran pendidikan multikultural berbasis proyek telah diuji coba pada kelompok kecil dan uji coba lapangan. Hasil uji coba menunjukkan produk layak digunakan, dibuktikan dengan peningkatan nilai yang signifikan pada kelas yang menggunakan model pembelajaran pendidikan multikultural berbasis proyek dibandingkan dengan kelas yang menggunakan model pembelajaran pendidikan multikultural dengan metode ceramah dengan media power point.

\section{Saran}

Model pembelajaran pendidikan multikultural berbasis proyek diharapkan dapat digunakan sebagai salah satu contoh variasi dalam pembelajaran sosiologi bagi guru. Model pembelajaran berbasis proyek dapat dikembangkan lebih lanjut dengan materi yang berbeda-beda dalam mata pelajaran sosiologi.

\section{Daftar Pustaka}

Asy'arie, M. (2004). Pendidikan Multikultural dan konflik bangsa. Diakses pada tanggal 28 Mei 2014 dari http:// 
www.kompas.com/kompascetak/0409/03/opini/1246546.htm

Banks, J. A. (2004). An introduction to multicultural education. Boston: Allyn Bacon.

Joice \& Weil. (1972). Contextual, complexcity, teaching style and models of teaching. Boston: the National Council for the Social Studies.

Lamer, J. (2015). Handbook of Project based learning. The Buck Institute of Education. Diakses pada tanggal 28 Mei 2014 dari http://bie.org/about/ what pbl

Mergendoller, J. R., et al. (2006). The effectiveness of problem based instruction: a comparative study of instructional methods and student characteristics [Online]. Diakses pada tanggal 28 Mei 2014 dari http://docs.lib.purdue.edu/rjpb 1/vol1/iss $2 / 5$.

Patton, A. (2012). Work that matter: the teacher's guide to project-based learning. The Paul Hamlyn Foundation

Purworini, S. E. (2006). Pembelajaran berbasis proyek sebagai upaya studi kasus di SMP Nasional KPS Balikpapan. Jurnal Pendidikan Inovatif Volume 1 Nomor 2 Maret 2006.

Sagala, S. (2010). Konsep dan makna pembelajaran. Bandung: Alfabeta.
Soekanto, S. (2006). Sosiologi suatu pengantar. Jakarta: Rajawali Press.

Sugiyono. (2010). Metode Penelitian Kuantitatif Kualitatif dan $R \& D$. Bandung: Alfabeta.

Suprijono. (2011). Cooperative learning. Yoyakarta: Pustaka Pelajar.

Thiagarajan, S., Semmel, D. S., \& Semmel, M. L. (1974). Instruction development for training teacher of exeptional children. Bloomington Indiana: Indiana Univercity.

Thomas, J. W. (2000). A review of research of project-based learning. Diakses pada tanggal 28 Mei 2014 dari http://www.bie.org/research/study/rev iewofprojectbasedlearning/2000

Trianto. (2010). Mendesain model pembelajaran inovatif-progresif. Jakarta : PT. Kencana.

Widjajanti, E. (2008). Kualitas lembar kerja siswa. Makalah pada kegiatan pengabdian pada masyarakat dengan judul "pelatihan penyusunan $1 \mathrm{ks}$ mata pelajaran kimia berdasarkan kurikulum tingkat satuan pendidikan bagi guru SMK/MAK di ruang sidang kimia FMIPA UNY pada tanggal 22 Agustus 2008.

Yaqin, A. (2005). Pendidikan multikultural: cross-cultural understanding untuk demokrasi dan keadilan. Yogyakarta: Pilar Media. 